\title{
The Burden of Difference? School Welfare Personnel's and Parents' Views on Wellbeing of Migrant Children in Finland
}

\author{
MINNA SÄÄVÄLÄ, Ph.D., Senior Researcher \\ The Population Research Institute, Väestöliitto, Helsinki, Finland.
}

\begin{abstract}
The school welfare system faces a challenge in the linguistically and culturally diversifying school. This article examines how school welfare personnel, native language teachers, and migrant parents conceptualize the wellbeing of migrant children in Finland. The data analyzed by thematic content analysis consists of group and individual interviews of a total of 47 persons: nurses, psychologists, social workers, a headmaster, special education teachers, native language teachers, and migrant parents in the Helsinki metropolitan area. The school welfare professionals' and migrant parents' views stressed different factors as risks and resources of migrant children's wellbeing. In school welfare personnel's view, school wellbeing is secured by downplaying difference between children of diverse cultural backgrounds; moreover, they do not see negative attitudes, discrimination, or bullying of migrant children as a particular problem. Migrant parents and native language teachers in turn consider or at least fear their children's wellbeing to be jeopardized by social exclusion, prejudice or discrimination. The school personnel find it difficult to recognize the power imbalance between minorities and the national majority that lies behind these different conceptualizations. This reduces trust and impedes the cooperation of migrant homes and school, particularly in situations when an intervention is imperative for securing child wellbeing.
\end{abstract}

Keywords: migrants, wellbeing, school, family, bullying, home-school interaction, social exclusion

\section{Introduction}

School is rapidly diversifying culturally and linguistically as a result of growing immigration and the relatively higher total fertility among immigrants. Foreign-born women have a total fertility rate (TFR) that is 0.3 children higher than among those women who were born in Finland (Statistics Finland 2011). In Helsinki the proportion of foreign language speaking children is currently 14 percent among children in 
primary school age ( 7 to 15 ) and over 16 percent of the children attending primary school participate in the teaching of Finnish/Swedish as a second language (City of Helsinki Education Department 2010). The proportion of foreign language speaking children is estimated to grow to 20-25 percent within a decade (City of Helsinki Urban Facts et al. 2010). This witnesses to the culturally diverse background of the student population and the growing challenges to the Finnish comprehensive school system. Fast cultural and linguistic diversification in schools prompts the school personnel, both teachers and others, to learn to cope with the situation and to find means to secure the equity and learning achievements of children of all backgrounds.

The challenge to a Nordic welfare society such as Finland is how the social services are able to cater for the structurally disadvantaged groups in order to level down disparities in wellbeing. Migrant children are a disadvantaged group at risk that needs special attention in service provision. Services of the welfare state are not only treating their subjects as citizens with equal rights but also as "humans in need of guidance and care" (Hagelund 2009, 97). This double relationship binds together control and welfare, and implies a power relation that can be described by the concept of "governmentality" (e.g. Dean 1999) which is particularly relevant for understanding how social services and educational institutions deal with minorities and other vulnerable groups, such as migrants. From a critical perspective, school is an arena of power relations where children are expected to grow into productive citizens and where the inequalities and hegemonies in society are reproduced.

School does not exist only for cognitive purposes. Along knowledge building, school is officially expected to secure and enhance children's wellbeing (Rimpelä, Fröjd and Peltonen 2010: 33, Child Welfare Act L417/2007, 12 §; Basic Education Act 628/1998, 31 a§). Anne Konu and Matti Rimpelä (2002) have formulated a theoretical model of school wellbeing based on Erik Allardt's conceptualization of wellbeing: having, loving, and being, including both objectively measurable health indicators and subjectively experienced factors (school conditions, social relationships, means for self-fulfillment, health status). Meiju Räsänen and Joel Kivirauma (2011) in turn have conceptualized school wellbeing around three central issues that stress the subjective, experienced aspects: social relations, the experienced importance of school and the experience of meaningfulness of school. A point of view which remains relatively less developed in both of these conceptualizations of school wellbeing is the school as an institutional domain of public authority and power and how that institutional role, along with power imbalances in society, affects school wellbeing of various sub-groups of children. The "health-promoting school" approach (Gray, Young and Barnekow 2006), raises the issues of democratic practices, participation, equity, and empowerment to the center stage in understanding school wellbeing. Health promoting activity both in adults and children is affected by their self-esteem, optimism, belief in change, and their assessment of what others think of them and their group (ibid. 15). 
In this study, we will examine the underpinnings of experienced and observed school wellbeing in a culturally diversifying school, particularly taking into account the different models of school wellbeing and paying particular interest in the health promoting perspective that is moored in participation, equity, and inclusion. What do the views and conceptualizations of the school welfare personnel as well as of migrant parents tell us about the importance of power asymmetries in explaining the wellbeing of migrant children ${ }^{1}$ ?

The health and wellbeing of immigrants and their children has been a topic of a plethora of empirical studies in Europe and beyond. However, no simple and straightforward conclusions have been reached concerning health disparities between migrant and non-migrant children (see e.g. Goodman et al. 2008; Hinzpeter et al. 2008; Malin et al. 2011; Stevens and Vollebergh 2008). Studies on migrant children's wellbeing have been few in Finland. ${ }^{2}$

Despite the country and ethnic group specific results in empirical studies, it is evident that immigration is a process that creates certain risks for the health and wellbeing of children due to the effects of the migration process on parenting and family relations (e.g. Alitolppa-Niitamo 2010; Suarez-Orozco and Suarez-Orosco 2001). In addition, many migrant families are socio-economically in a disadvantaged situation, characterized by downward social mobility after migration which tends to increase the risks to health and wellbeing among the children, and minorities easily attract prejudice and discrimination which creates stress and affects mental health (Malin 2011).

One of the few quantitative studies on school wellbeing among migrant children in Finland was recently carried out in the city of Turku. Immigrant children appreciated school more than their non-migrant peers and also their general school wellbeing was better (Räsänen and Kivirauma 2011). When evaluating Räsänen and Kivirauma's (2011) very positive survey results concerning school wellbeing among migrants, we should keep in mind the problem of studying subaltern groups: satisfaction to school among migrants may be somewhat overstated in a survey that is identified as a representative of hegemonic society.

This article does not deal with the actual school wellbeing or state of health among immigrant children but with the conceptualizations of that wellbeing among immigrant parents and school welfare personnel who are the significant others whose duty it is to

\footnotetext{
${ }^{1}$ By migrant children we refer here to both those children who are migrants themselves (first generation) and those children whose parent(s) are migrants (second generation). The interviewees most commonly interpreted "migrant children" (maahanmuuttajalapset) to include only those children who did not have any Finnish parent which means that children of bicultural homes are usually not included in the discussion.

${ }^{2}$ See Räsänen and Kivirauma (2011) on school wellbeing; Soilamo (2006) and Strohmeier, Kärnä and Salmivalli (2011) on school bullying; Kääriäinen et al. (2010) on experienced violence; Hermanson and Lommi (2009) on health status of immigrant youth.
} 
look after children's wellbeing at school. Neither is this a study on interpretive repertoires or discourse per se, such as e.g. Anniken Hagelund's (2009) study of diversity workers or "street level bureaucrats" in Norway. The theoretical frame of reference derives from critical realist approach to social reality and language: the focus is on the relationship between discursive statements and social relations. What are the factors in social reality which make certain discursive formulations intelligible? Understanding of the school welfare personnel's and parents' views and conceptualizations is essential when policy decisions are made on institutional practices concerning migrant children's health, wellbeing and equity in the school welfare system and health services.

\section{Data and methodology}

The data of this study is qualitative and collected by the researcher and two research assistants in two phases in a municipality in the metropolitan area of Helsinki. The research data consists of interviews of three groups of respondents:

1. School welfare personnel (school health nurses, school psychologists, school social workers, special education teachers and a headmaster):

a. 4 focus group discussions: 19 participants in total

b. 5 individual expert interviews

2. Native language teachers ${ }^{3}: 10$ interviews (Kurdish, Filipino, Polish, Russian, Somali, Thai, Turkish teachers)

3. Immigrant parents: 13 interviews (Kurdish, Russian and Somali speakers).

In total, the data consists of the views of 47 persons, gathered either in individual interviews or in group interviews. Apart from the data on immigrant parents, the interviews were carried out in 2010-2011. Official permissions were secured from the municipal authorities and each interviewee was given the necessary information on the study objectives and their voluntary agreement for the interview was asked for in writing.

Potential interviewees among school welfare personnel and native language teachers were identified with the help of the municipal education department and by the snowballing technique. The interviews were voluntary and took place mainly in schools. Most of the personnel interviewed worked in schools with relatively high concentration of foreign-language-speaking children so that they often had years of experience in everyday interaction with migrant children and their families. The interviews of immigrant parents were carried out in 2006 in relation to another study on home-school interaction (see Syrjänen 2008) and took place in a number of different places, from

\footnotetext{
${ }^{3}$ Native language teachers teach foreign language speaking children their own native tongue for 2 hours a week. Participation is voluntary. In practice, the teachers of native languages act as cultural brokers between the school and the families. Immigrant parents and guardians easily turn to them if they face a problem relating to their children as the teachers speak the same language.
} 
libraries to cafes and homes. In this article, the main focus lies in the interviews of the school welfare personnel and parents. Native language teachers' accounts are used as supplementary data.

The individual interviews were semi-structured, free-flowing thematic interviews that aimed at mapping the interviewee's personal experiences and views, while the focus group interviews concentrated on creating an image of the ideologically important, shared or contested views on school wellbeing and migrant children among particular professional groups. The focus groups consisted each of different professionals: a group of nurses, a group of psychologists and so on. In addition to the views and conceptualizations of migrant children's health and wellbeing that are analyzed below, the data consists of data on home-school interaction, diagnosing of health problems and generally on migrant parents' attitude towards school (see Syrjänen 2008; Säävälä 2012; Weckström 2011).

Research ethics has created particular requirements for the collection and reporting of research data on the sensitive topic. School personnel cannot take up any particular, recognizable individual cases in research interviews due to confidentiality. This affected the interviews so that the interviewees maintained a relatively high level of abstraction in their statements. As some of the interviewees were strongly opinionated and brought out views that could be potentially used against them as holders of public office, it has also been important to secure in the best possible way the anonymity of the personnel's statements. Consequently the personnel's work places, languages of the native language teachers, and the municipality are unrecognizable in the use of quotes. Most important has been to secure the migrant families' anonymity as they are in a vulnerable position. They have revealed issues related to their intimate family life and children's health in the interviews. The highest ethical guiding principle of this study has been the need to secure children's interest, although they have not been directly the subjects of data collection.

The interviews were transcribed verbatim and the interviews of some parents that were carried out in a foreign language were translated into Finnish. The method of analysis was qualitative content analysis: "qualitative data reduction and sense-making effort that takes a volume of qualitative material and attempts to identify core consistencies and meanings" (Patton 2002, 453). The practical approach was "directed content analysis" (Hsieh and Shannon 2005)in which initial coding starts with a pre-existing theory or relevant research findings, in this case Rimpelä and Konu's (2002) model of school welfare. When immersing oneself into the interview data, themes derived from this model (school conditions, social relationships, means for self-fulfillment, health status) were extended, transformed, and supplemented by new coded themes and added by sub-themes. When grouping the interview statements within theme categories, four major, cross cutting abstractions were discovered as meaningful for understanding 
the point of view different actors took to migrant children's school wellbeing: equity, cultural difference, language barrier, and family diversity. The basic research question is, what conceptual frame of reference relating to child wellbeing the personnel uses in their discourse concerning migrant children's wellbeing and how this juxtaposes with migrant parents' ideas of their children's wellbeing at school. In the following, interviews of all three groups (school welfare personnel, native language teachers, and migrant parents) are presented and juxtaposed to examine the discrepancies and uniformities in the views of these actor groups.

\section{No specific risks perceived among migrant children}

The general attitude among school welfare personnel towards migrant children's wellbeing was very positive, manifesting an abstract feature that was present in many interview accounts: the denial or downplaying of difference. They did not consider children of immigrant families as particularly prone to have such problems that are brought to be discussed in the pupil welfare team's (oppilashuoltoryhmä) meetings. Among typical individual cases these teams deal with are shifts to special education, assessing the need for psychological tests due to learning or behavioral problems, solving cases of bullying and truancy, and taking action in child protection cases. The personnel interviewed did not consider immigration background as a risk to child wellbeing and some vehemently objected the view that migration background per se would somehow affect the wellbeing and health of these children:

Immigrant children are represented in our student welfare quite in the same volume that they exist among the group. ${ }^{4}$ So that they do not appear in proportion more often in student welfare than others. But those with whom there are problems, those problems are more challenging than with Finnish parents, because there is the language problem and secondly the cultural problem, a problem is not maybe the right word, but when we start speaking about investigation and so on, then we would need - not only an interpreter - but also cultural interpreter, that what we mean by this, what we are after here. ${ }^{5}$ (Headmaster of a lower primary school)

The headmaster saw the situation of immigrant children as comparable to other children. The question of language and cultural difference, however, made interaction with the families more demanding and created complications in solving problematic situations.

\footnotetext{
${ }^{4}$ Quotations are translated from Finnish by the author. When the speaker in the parentheses is in singular, the quotation is from an individual interview, when in plural, the quotation is from a group discussion. Words in [brackets] are added by the author to clarify the meaning. The original quotation in Finnish is given in the footnote.

${ }^{5}$ Maahanmuuttajalapset ovat meidän oppilashuollossa edustettuna ihan sillä volyymilla mitä he on täällä muutenkin joukossa. Ettei heitä ole prosentuaalisesti yhtään enempää pyöri oppilashuollossa kun muitakaan. Mutta ne, joiden kanssa on ongelmia, ne ongelmat on haastavampia kun suomenkielisten vanhempien kanssa, koska siihen tulee ihan ensimmäisenä kielellinen ongelma ja toisena kulttuurinen ongelma ei ehkä ole oikea sana, mutta kun me ruvetaan puhumaan tutkimisesta tms. asioista niin siinä tarvittais - ei pelkkää tulkkia - vaan myös kulttuurintulkkia että mitä me tällä tarkotetaan, mitä me haetaan.
} 
The same downplaying of difference was manifest behind many other statements - that it all boils down to language barrier:

I have not really noticed that it would be, that being immigrant in itself would be any big risk. Let's say that the language skill is actually essential. ${ }^{6}$ (Special education teacher)

Some of the interviewees felt it very difficult even to ponder about the whole issue of potential differences between migrant and other children. The same reluctance or uneasiness came also up when differences between children of economically poor and better-off families was raised in the interviews. Evidently school welfare professionals deal with children as individuals and do not want to jump to any generalizations. It is possible that they have become so aware of the danger of negative stereotyping that they prefer not to delve into any generalizations at all. The same "playing down health differences" -attitude existed also among the native language teachers who felt that the children they teach do not suffer from any specific difficulties.

The diversity of immigrant families and children raised interviewees' attention: they felt that it is difficult to generalize about migrant children as their backgrounds are so diverse and they live in such different conditions and social situations. It was apparent that some of the interviewees felt that even raising this kind of general questions concerning the health and wellbeing risks among migrant children implies that they are underdogs which the interviewees were reluctant to accept or support. The personnel does not seem to be aware of the generally poor economic situation of the majority of migrant children: more than 60 percent of foreign language speaking children are in the two lowest income deciles (Malin 2011). The same applies to the prevalence of single parenthood: the proportion of single parents is considerably higher among some immigrant groups than in the mainstream society. For example, every other Somali speaking family with children is a family of a single mother (Statistics Finland 2010, additional table no 5). These topics - prevalence of poverty and single parenthood - did not come forward spontaneously in any of the interviews, and even when they were addressed by the interviewer, they often raised understating comments or uneasiness. The growing poverty among families with children in Finland (Vaarama et al. 2010) seemed to be a topic that is difficult for the grass-roots level workers in schools to acknowledge. Many felt that income differences are insignificant for the wellbeing of children, only visible in some parents' inability to indulge in conspicuous consumption or to pay for costly hobbies such as ice hockey or horse riding.

Generally speaking, the interviewed migrant parents, in turn, expressed worry about their children. The risks to their children's wellbeing that came up in the interviews all originated outside the family and ethnic group, in the Finnish or global reality: in the

\footnotetext{
${ }^{6}$ Mä en oikeastaan ole huomannut, että olis, että se maahanmuuttajuus sinänsä olis kamalan suuri
} riskitekijä. Sanotaan se kielitaitohan on oleellinen. 
Internet, in the Finnish peer group, and in some interview accounts in the discrimination faced by their ethnic or national group in Finnish society generally or in school. Immigrant parents themselves felt relatively helpless in terms of their children's wellbeing. They considered themselves as able parents who know what is good for their children but they did not know how to control the influences that they saw as harmful for their children, coming from the Finnish everyday reality. (Säävälä 2012.)

\section{Identifying mental problems}

When probed further, the picture of migrant children presented by the welfare personnel turned out to be more nuanced than the initial denial of difference let us believe. One of the issues that raised lively discussion among the more experienced school welfare professionals was migrant children's psychological wellbeing. Although school welfare personnel did not consider migrant children as particularly prone to suffer from mental problems - on the contrary, they were commonly described as being in good humour and more enthusiastic to learn than majority children - the topic raised many statements. The professionals' image of migrant children's mental wellbeing can be termed as a psychological enigma. Some brought out the difficulty of recognizing migrant children's psychological problems as they saw the ways of Finns and foreigners as very different in expressing such problems:

- They feel that it is shameful, a shame, if such a psychological problem [is diagnosed], they do not have... I think someone said that they do not even have a word for it, when they have...

- Only the extremes [are recognized], and no one wants their own child in that [situation]...

- And learning disability may be categorized as a psychological problem, indeed (others in the background are nodding in agreement)

- And particularly if there is some behavioral problem and they would want, or if there is depression or something else like that, these have been very difficult situations to get the parents to understand, that now some help is needed in this. ${ }^{7}$ (Nurses)

Categorizations of problems were considered to be different so that for example the dissimilarity between learning disabilities and psychological problems may not be apparent to parents. Overall, the main issue hindering migrants from bringing up their problems and being helped was thought to be the experience of shame - based on cultural difference. A nurse described in an individual interview how challenges in integration and learning the new language and tensions related to these may be somatized, expressed in the form of head ache or stomach cramps:

\footnotetext{
${ }^{7}$ He kokevat että se on häpeällistä, häpeä, jos tämmöinen psyykkinen ongelma [todetaan], ei heillä ole siinä... Joku minusta sanoi, ettei heillä ole edes sanaa sille, että on..

- Ä̈ripäät vain ja siihen ei kukaan halua omaa lastaan.

- Niin ja oppimisvaikeudet ehkä mielletään siihen.. Että se on psyykkinen pulma just (myöntelyä taustalla). - Ja varsinkin jos on jotain käytösongelmaa ja haluttaisiin, tai jos on masennusta tai muuta sellaista niin ne on olleet hirveän vaikeita tilanteita saada vanhemmat ymmärtämään, että tässä tarvittaisiin nyt jotain ариа.
} 
There is evidently that they react, psycho-somatic symptoms, stomach problems and.. Headache maybe more because they have it difficult with the language. It is difficult, and the adolescent and child possibly her/himself does not realize, that it is a difficulty with the language. Tension symptoms, there is yes. ${ }^{8}$ (Nurse)

A social worker described the difference between contemporary Finnish young people and immigrant youth in their way of talking about their inner feelings such as sorrow, worry or general mood. She said that "psycho talk" has become part of the young people's idiom during the last decade so that adolescents do not feel any shame or reservation to speak about depression, anxiety, eating disorders or neurotic symptoms. On the contrary: medicalization of mental states is audible in young people's idiom. According to a social worker with decades of experience working with school children, they no more fear stigmatization of being mental. But the social worker felt that this is still not the case among migrant youth who lack such "psycho talk":

But the foreigners do not speak about these things. They start from the idea that everything is fine, everything is quite fine when you ask them how they are. So in nearly all the cultures they hide the bad feeling, indisposition as long as possible, they do not come to talk about that. Whether it is about oneself or about one's family, they are actually not allowed to speak about it to anyone, it is more forbidden. It cannot be opened up, it certainly would stigmatize them and their family and also themselves, if they happen to get into such a conversation. So talking about these issues is more difficult. But then on the other hand, foreigners talk, young people talk about that they do not do well in a subject at school, saying "I should get better teaching in Finnish language as I do not get along now, or I'm having it a bit difficult". So they ask help for a certain subject, getting along and those issues. They come eagerly and much easier to talk about that. ${ }^{9}$ (Social worker)

According to the social worker, these young people will more eagerly dress their anxiety or worry in the form of talking about their school achievement or their need for supplementary teaching instead of revealing any inner feelings or problems at home. If they go to see the school nurse, they express their anxieties easier in the form of somatized symptoms such as headache or stomach problems. According to

\footnotetext{
${ }^{8}$ Mutta jos ajattelen, niin on tietysti tällaista että reagoi, psykosomaattista oireilua, vatsavaivaa ja.. päänsärkyä ehkä enemmänkin sen takia, että on kielen kanssa vaikeeta. On vaikee, nuori ja lapsi ei itse sitä ehkä tiedostakaan, että on kielen kanssa hankalaa, vaan muuten. Jännitysoireita, on kyllä

${ }^{9}$ Mutta ulkomaalaisetpa ei puhukaan näistä asioista. He lähtee siitä että kaikki on hyvin, kaikki on oikein hyvin kun heiltä kysyy et mitä sinulle kuuluu: Hyvää kuuluu. Eli melkein kaikissa näissä kulttuureissa piilotetaan se paha olo, pahoinvointi niin pitkälle kuin mahdollista, siitä ei tulla puhumaan. Liittyy se sitten omaan itseen tai perheeseen niin sitä ei oikeastaan saakaan puhua kenellekään, että se on kielletympää. Sitä ei saa avata, se varmaan leimaa heitä ja heidän perhettään ja heitä itseäänkin, jos semmoseen keskusteluun ikään kuin joutuu. Elin näiden aihealueiden kanssa keskustelu on vaikeampaa. Mutta sen sijaan ulkomaalaiset puhuu tästä nämä nuoret että kun koulussa ei pärjää jossakin oppiaineessa, että minun pitäisi saada parempaa suomenkielen opetusta kun minä en nyt oikeen selviä, tai minulla on vähän vaikeaa. Eli apua tähän oppiaineessa etenemiseen, sujumiseen ja niihin kysymyksiin. Siitä he puhuvat mielellään ja paljon helpommin.
} 
the nurses, psychologists, and social workers who had long experience in working with migrant children and families, it is much more demanding to get to the root of the problems of migrant children. This means that problems tend to become serious and complicated before they bulge to the surface. In the eyes of the school personnel, migrant children keep up a very high "happiness barrier" (Roos 1988) in order to protect themselves, their family and their ethnic or national group against negative attention and stereotyping.

\section{Family as a risk or resource?}

Among the school welfare personnel, migrants are generally see as living a familycentered life in which authority is more pronounced than among the non-migrant families. This was thought to manifest, among other things, in the children's rules, schedules, and choice of company. There were also interviewees among the personnel who were of the opinion that migrant children were actually better positioned than non-migrants in terms of wellbeing and health: I do not experience them having any of these problems [of others] that much. ${ }^{10}$ They explained this by reference to stricter authority and familism that keeps them away from drinking alcohol, eating disorders, too little sleep and exercise, too long hours in the Internet, and the effect of breakup of family relations. Thus some of the professionals interviewed contemplated whether migrant background would actually be an asset for physical health.

The moral value given to the migrant family depended on the framing of the commentary so that in some situations the interviewees stressed the beneficial and morally good effects of familism, but in some other contexts familism gained a negative value as counter-effective to child wellbeing. Authoritarianism was thought to create problems if it was very tight, although the problem among the majority children was thought to be the opposite: too lax rules which show for example in bed time, curfew, and meals (Säävälä 2012). However, psychologists pointed out in their discussion that it is impossible to make generalizations concerning migrant families in terms of their authoritarianism:

And those with immigrant background, depending also on how long they have been in Finland, and depending on how the families are cooperating; discipline varies. Others are maybe more lax, others even really strict, which does not necessarily come up in a school palaver. ${ }^{11}$ (Psychologists)

According to the native language teachers the inconsistency between school and migrant homes has to be constantly worked on. They see that their cultural approach to family relationships and family norms is clearly different than among the major-

\footnotetext{
${ }^{10}$ En koe että heillä olisi niinkään tällaisia ongelmia [samanlaisia kuin muilla] niin paljon.

${ }^{11}$ Ja mamutaustaisilla riippuen siitä kans kuinka pitkään on asunu Suomessa ja miten he perheet on yhteistyössä tai vaihtelevaa siellä on se kurinpito. Toiset on ehkä lepsumpia, toiset tosikin tiukkoja, mitä ei välttämättä nouse koulupalavereissa.
} 
ity which creates conflicting situations for the migrant children. One of the native language teachers explained that she does not appreciate all the cultural practices and ways of thinking in her own ethnic group, but still, she has had to learn to mitigate these inconsistencies and conflicts:

Culture, it is a bit different than the culture in Finland. In Finland upbringing is different than our way of bringing up. Sometimes we speak about friendships and school rules and how to solve conflicts and so on, all these things are very different for them at home. That is why I am annoyed that all the time we have to discuss, every lesson almost 15 or 10 minutes in the beginning, all the time I am speaking to them about these things, about what is the attitude and way of thinking about these things in Finland. ${ }^{12}$ (Teacher of a Middle-Eastern language)

A few of the migrant parents also mentioned that some families themselves create problems for the children due to child abuse or father's authoritarianism. One parent asserted that school will never get to know about these issues:

I have many family friends that have big problems and children have not told about these at school. The teachers know nothing, they can only guess that there is some problem in the family ${ }^{13}$ (Russian-speaking mother).

The issue of child abuse was a touchy topic and aroused a lot of discussion in all the three groups of interviewees. The school welfare personnel were outspoken in their rebuttal of the issue being particularly relevant for migrant families. In all the professional groups, there was an evident need to deny the image of the migrant family as violent. Some special education teachers said that they had never met up with such cases despite teaching migrant children for years, and some stressed that there is quite likewise bad treatment in Finnish families showing up (Social workers). Cases of child abuse are not everyday occurrences in schools, but when such a case surfaces, it leads to a conflict between school and home and may involve authorities and a legal process. In the group interview of psychologists it became evident that their views were divided on how and at what point school should take action in case they suspect child abuse and how to interact with the parents in such situations.

Migrant parents themselves considered their families fundamentally different from what they regarded as a "Finnish family": our family is altogether different from a Finnish family (a Kurdish-speaking parent). This felt difference could lead to conflict especially when issues of disciplining came under scrutiny. Some of the interviewed parents felt that physical disciplining, which is illegal in Finland, is the best way to secure their child's

\footnotetext{
${ }^{12}$ Kulttuuri, se on vähän eri kulttuuri kun mikä on Suomessa. Kasvatetaan Suomessa eri tavalla, kun mitä me kasvatetaan lapsia.. Joskus puhutaan ystävyydestä ja koulun säännöistä ja ristiriitatilanteiden selvittämisestä ja näin, kaikki nää asiat on heille ihan eri juttu kotona. Se takia mua harmittaa, koko ajan pitää keskustella, joka tunti melkein 15 min tai 10 min alussa, aina kun mä puhun näistä asioista kaikkea heille, että miten he suhtautuvat täällä Suomessa.

${ }^{13}$ Mulla on paljon tuttuja perheitä, joissa ovat isot ongelmat ja lapset eivät ole kertoneet niistä koulussa. .Opettajat ei tiedä mitään, voivat vain arvata että perheessä joku ongelma.
} 
wellbeing. The major problem according to some of the Russian interviewees was the lack of discipline in the Finnish school. Authorities who intervene in child abuse were considered by some interviewees as discriminatory, only raising charges against foreign parents and turning a blind eye to Finnish parents doing the same. (Säävälä 2012.)

Views on physical punishment are the apex of difference between Finnish society and the migrant parents' self-understanding. Although some of the interviewed migrant parents vehemently disapproved of using violence as a form of disciplining a child, many understood it differently than Finnish authorities and the majority. "Mild" physical abuse (slapping, flogging and the like) would be beneficial for the child in the long run, and distinct from "child abuse proper" - violence that harmed the child and caused visible injuries. Some of the native language teachers confirmed the existence of this binary view amongst their own ethnic or linguistic group. They tried to act in between as cultural brokers who explained to the Finnish school how their own cultural group thought and acted and on the other hand, tried to make the point of view of the Finnish school intelligible to the parents.

\section{Parents' concern: Social exclusion and discrimination}

The worries of migrant parents over their children's school wellbeing concentrated around social wellbeing and securing equity. There were interviewees among parents, native language teachers and also school welfare personnel who experienced social isolation and lack of appreciative inter-group contacts as a stumbling block for migrant children in their quest for school wellbeing. Worries relating to social connectedness were the most explicit in the statements of the parents and the language teachers. A teacher of a Middle-Eastern language was concerned about isolation and would have liked to see everyone playing with everyone else:

In the courtyard during a break they [children of her ethnic group] only play among themselves, I see that they do not play with others. This is a bad thing in my opinion, everyone should be playing together. This means that integration is a bit weak. ${ }^{14}$

The feeling of being regarded as second-rate citizens in Finland came forcefully through in some accounts of the parents, and related to social connectedness. A Kurdish-speaking father brought up his sadness vis-à-vis the interminable migrant identity of his children:

So at school they [his children] are passed comments. It gives the feeling that children can get marginalized due to that. (..) It is sometimes as if they do not feel that well. (...) Also our children noticed that they are migrants, although they are not migrants, they are born here. And this has been taught in school. Before they went to school, they did not think that they must have been born elsewhere. That is, no

${ }^{14}$ Pihalla välitunnin aikana he leikkivät vain keskenään, mä katson, ei niinkun, eivät leiki muiden kanssa.. Tää on huono juttu mielestäni, pitäisi olla niinku kaikki yhdessä. Että kotoutuminen on vähän heikkoa. 
matter how fluently they speak Finnish - these children of ours speak fluently - they are constantly passed comments like "you are migrants". ${ }^{15}$

This father felt that behind his children's unhappiness were issues relating to identification and the constant reminder by the majority of their migrant status, despite being born in Finland. He felt that the majority forced his children to be minority children and thus kept them in a marginal position. He also noted that there are some migrant communities who themselves strengthen this division and build up the difference deliberately, to the disadvantage of the children.

Parents' experiences and views on bullying and discrimination were quite varied and did not support any straightforward conclusions about the prevalence of experienced bullying. Some tersely denied the existence of any bullying related to their ethnic or racial background; some said that bullying was more common for other reasons and some felt that bullying of their ethnic group was a big problem for their children and themselves.

The main issue for the parents was how the school personnel reacted to bullying by other pupils and the danger of being discriminated by the school staff themselves. Some felt that their family was treated differently due to their migration background:

In that place where my son is studying, teachers treat foreigners a bit differently. That means, they pay attention to what the foreigners do. If a Finnish child does something [wrong], they ignore. For example if there is a lesson, and a student starts speaking and raging, the teacher always accuses the foreign students. Although it is often Finnish kids who start it and foreign kids just carry it on. ${ }^{16}$ (Russian-speaking mother)

Some had bad experience both from the school children and the adults at school. A number of examples came up in the interviews although they appeared to be rather concentrated so that some people had a lot to complain and some others did not have any experience of discrimination that they would feel a need to share. According to some interviewed parents, the school adults are more eager to believe in the version provided by Finns in case bullying comes up. Cases when their children are badly treated as not taken seriously:

But if a Somali child is mishandled, yelled at or maltreated, then they try to hide the issue, so that they are not discussed in the same way, both cases. ${ }^{17}$ (Somalispeaking mother)

\footnotetext{
${ }^{15}$ Meidän lapsetkin huomasi, että ne on maahanmuuttajia, vaikka ne eivät ole maahanmuuttajia vaan ovat syntyneet täällä Suomessa. Ja näin on opetettu koulussa. Ennen kuin ne lähtivät kouluun, ne eivät ajatelleet, että ne ovat syntyneet jossain muualla, vaikka ne ovat syntyneet täällä Suomessa. Siis vaikka kuinka sujuvasti ne puhuu suomenkieltä, nämä meidän lapset kun he puhuu sujuvasti suomea mutta koko ajan ne huomauttaa niille, että te olette maahanmuuttajia.

${ }^{16}$ Siellä missä mun poika opiskelee, opettajat vähä käyttäytyy ulkomaalaisia kohtaan eri tavalla. Että vähän katsoo, mitä ulkomaalaiset tekee. Että jos tekee joku suomalainen lapsi, niin katsovat vähän sormien läpi. Esimerkiksi kun oli joku tunti, ja joku opiskelija alkaa puhua ja riehumaan, niin opettaja aina syyttää ulkomaalaisia lapsia. Vaikka usein aloittavat suomalaiset ja ulkomaalaiset vain jatkavat tunnin häiritsemistä.

${ }^{17}$ Mutta jos toisinpäin käy ja somalialaisia lapsia loukataan, huudetaan, tehdään heille jotakin pahaa, silloin halutaan asia peittää, että asiasta ei keskustella samalla lailla, molemmat keissit.
} 
The interviewed mother had contacted the school social worker because some others had drawn an ugly picture of her child with bad names. The school had taken up the case and allegedly handed it over to the police. However, the family had not heard anything about the incident ever since and neither had they themselves made any inquiries. Cases in which the school had failed to contact the parents in bullying incidents or behavioral problems of their children received a lot of criticism from a number of interviewed parents. These situations had created in them the feeling that their family is not treated equally in school.

\section{School welfare personnel: Equity secured}

This worry concerning unfair treatment and bullying that came forcefully through in the migrant parents' interviews as an issue, no matter if they themselves had been discriminated or not, remained marginal from the point of view of the school welfare personnel. According to them, discrimination or bullying based on ethnic or racial group is not a phenomenon of much importance at school. Their way of speaking about the issue showed that there is a great need to deny the existence of bullying of migrant children:

And only few experience racism, I think rarely they say that they would experience. When thinking about it, many of them start to be like, they have been born in Finland, in a way the situation has developed that far here. ${ }^{18}$ (Nurses)

Nurses believed that being born in Finland and knowing the language would remove racism and discrimination from the agenda of migrant children. Psychologists in turn discussed whether there are cases of bullying among migrant children that come to be handled in the pupil welfare team. They came to the conclusion that migrant children are not involved in bullying cases particularly often:

- Of course I also get to know about issues, but I don't know if it [bullying] is more common than for any other reason, that is, based on appearance or any other basis for bullying. And then if someone becomes a racist, he/she gets into trouble from the side of the other students because migrant children's loyalties are so strong in these issues so that the bullies get also very easily into trouble.

- In my school there are so few migrants, that they are no offence to anyone. There is no such [racist] dynamics either. ${ }^{19}$ (Psychologists)

One of the psychologists thought that discriminatory bullying which they referred to as "racism" was not probable because there were so many migrant children in the school

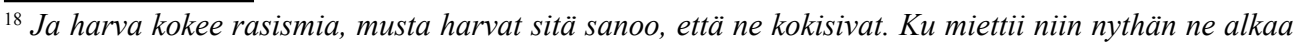
monet olemaan semmosia et ne on syntyneet Suomessa, tavallaan se tilanne on niin pitkällä täällä.

${ }^{19}$ - Totta kai sieltä tulee myös niitä kommentteja mulle päin, mutta en tiedä onko enempää kuin muista syistä, siis ulkonäöllisistä tai mistä tahansa kiusaamissyistä. Ja sitten joutuu monesti oppilaiden osalta aikamoisiin ongelmiin jos siellä rupee rasistiksi koska mamulasten ja nuorten lojaalisuus näissä asioissa on semmoinen että kiusaajat joutuu aika herkästi myös ongelmiin.

- Mun koulussa on niin vähän maahanmuuttajia prosentuaalisesti, et ne ei ole siinä uhkana kellekään. Ei ole semmoista dynamiikkaa myöskään.
} 
who would retaliate, while the other psychologist thought that bullying does not exist because migrant children are so $f e w$ in his school. Thus they both found explanations for the perceived lack of racist bullying even though the explanations were the opposites.

When discussing the topic further, the initial view on migrant children not suffering from bullying more than others became much more nuanced and contemplative. The psychologists also brought forward the issue of some adults at school being discriminatory and bullying migrant children:

- I am worried about the attitude of children and adolescents, but even more so about the school adults' [attitude], because it is socially accepted to present those [racist] opinions and ponder on these issues and say "we are surely not racists, are we", but have those problems been addressed properly?

- Of cleaners and janitors... At times we have had to intervene in their attitudes. Like also migrant children move around in that group of their own, so similarly there are sometimes these cliques of personnel that can be really nasty. More I am worried about that side than about that of the adolescents.

- I live there up in my own "castle in the air" in that little study of mine, and in my thoughts they all get along very smoothly [said ironically]. But those working in youth centers, they tell about a lot of this kind of things like calling names and...

- There is actually [discrimination but] it does not come through to my "caste in the air" either!

- We are all in the belief that everything goes quite fine, then! (Laughing ironically) ${ }^{20}$ [Psychologists)

When discussing the issue more closely with the psychologists, they brought out a rather ambivalent perspective on discrimination and bullying. They were aware of the nature of their duties and work cutting them off from the everyday reality of the students' peer groups, particularly in the upper primary schools, which reduced their opportunities to recognize bullying and discrimination. Each psychologist has to serve a very large number of pupils and schools, and to concentrate on diagnosing cases of learning disabilities and psychological problems, among other assignments. This difficulty of identifying bullying particularly in the upper primary school was brought up by other groups of school welfare personnel as well.

\footnotetext{
${ }^{20}$ - Mä oon myös huolissani lasten ja nuorten asenteesta mutta ennemminkin koulun aikuisten, koska se on sosiaalisesti hyväksyttyä esittää niitä mielipiteitä ja pohtia niitä asioita ja "eihän me kukaan olla rasisteja", mutta onko niitä ongelmia kohdattu oikein?

- Sitä siivoojien ja huoltomiesten välillä ollaan jouduttu puuttumaan heidän asenteisiin. Niin kuin myös mamulapset ja nuoret kulkee siinä porukassaan, niin välillä on myös henkilökunnan kuppikuntia mitkä on tosi inhottavia. Enemmän huolettaa se puoli kuin lasten ja nuorten puolesta [tapahtuva syrjintä].

- Mä elän täysin siellä omassa pilvilinnassani siellä kopissani ja mun pilvilinnassani he tulee tosi sulavasti kaikki toimeen. Mutta nuorisotalon työntekijät, heiltä tulee nyt tosi paljon [esiin] tällaista nimittelyä ja...

- Siel kuitenkin on [rasismia, mutta] ei se munkaan pilvilinnaan tule!

-Me ollaan siinä uskossa, et menee ihan hyvin siis! (nauraa)
} 
Nurses, as well as the social workers in their group discussion, spoke at length about the new phenomenon of animosities between some migrant groups. Another issue, which the psychologists and some others, too, in individual interviews, brought up were the attitudes of the adults in school and some prejudiced members of the personnel that were much more difficult to intervene than the actions of children. Discrimination and bullying of migrant children was initially denied but recognized when addressed less directly. Also native language teachers had a divided viewpoint concerning the prevalence of bullying. Some said that children had told them about bullying due to their appearance or ethnic background, while other teachers denied any existence of such kind of school bullying:

We are not bullied... There is nothing, no bullying has taken place in front of me, at least (laughs). (Teacher of an Asian language)

No such problems have been occurring, or at least now, during the last years, there has not been any serious racism or like that.(..) Yes, there can sometimes be problems among children, a child may think that it is racism even if it is not any kind of racism (laughs), that can occur some [disagreement] in the courtyard and then, we intervene straight away. So that there will be no bullying or something. ${ }^{21}$ (Teacher of an African language)

The first quote of an Asian teacher started with a personal pronoun "we" - she was concerned whether her ethnic group as a whole faces discrimination and strongly identified to the group of children. The answer seems to imply, between the lines, that some other group of migrants might be bullied, unlike her group. She added, "in front of me, at least" which has an apologetic air that leaves the possibility open that there might be some bullying that she is unaware. The second quote of a teacher of an African language wanted to explain that racist bullying does not exist anymore even though it had been there before. He also explained that children may sometimes claim racism even when the incident does not in closer scrutiny appear to be racism. All in all, the issue of discrimination and bullying was a touchy topic for native language teachers as well.

\section{Discussion}

The conceptual frame of reference concerning risks and resources of migrant children's school wellbeing used by school welfare personnel and migrant parents is not identical. For the school personnel, migrant children's health is considered in the rather well-established mental, physical and social health context in which the problems of equity, participation and inclusion have only secondary relevance as risks. Cultural difference is recognized but not thought to cause any particular strain on child wellbeing - on the contrary, it is

\footnotetext{
${ }^{21}$ Ei paljon mitään ongelmia oo ilmenny, tai ei ainakaan nyt, viimeisinä vuosina ole ollut mitään, vakavaa rasismia tai mitään semmosta. (...) Kyllä lasten kesken voi joskus tulla jotain ongelmia, lapsi voi ajatella, että se on rasismia vaikka ei ole mitään rasismia (naurahdus), että voi tulla joku [riita] vaikkapa pihalla, tai kun he pelaa jalkapalloa keskenään, niin aina lapsille tulee keskenään jotain, mutta selvitetään heti saman tien, tai puututaan saman tien. Että ei tule mitään kiusaamista tai jotain.)
} 
seen primarily as an additional resource. For the migrant parents, their children's school wellbeing is first and foremost an issue of equity and participation. In their point of view, cultural difference can be a problem for their children only because Finnish society makes it a problem (see also Warsame 2011; Säävälä 2012). The biggest risks to their children's wellbeing come in parents' point of view from Finnish society: from peers' undesirable "Finnish" habits, bullying, teachers' unfairness, school's inability to contact migrant parents, or from dooming the children of migrants to be "migrants forever".

The native language teachers had a balancing view in-between, sharing partly the concern for improving migrant children's mental health, social inclusion and equity, while having a dual attitude to cultural difference as both a resource and as a potential source of health risks due to child abuse, authoritarianism or harmful health practices. The native language teachers at times find themselves helpless as cultural brokers between the two worlds that seem partly incommensurable and non-negotiable (Weckström 2011).

School welfare personnel's views were initially as if frozen by certain ideological givens: most evidently by the need to present an understanding of the migrant children and families as equal by denial of difference, and secondly by the need to ascertain the existence of equity and absence of negative stereotyping in the everyday life of the school. These ideological, taken-for-granted standpoints led to the commonly expressed views that migrant children do not face any particular risks of wellbeing compared to the non-migrant children, and that bullying, discrimination, and child abuse are not particularly relevant issues for migrants. The service professionals' need to deny or downplay bullying of migrant children or racist discrimination in Finnish schools and youth work has been recorded also in other studies, e.g. Honkasalo (2011), Rastas (2007) and Souto (2011). These uniformalizing views did not reflect the school welfare professionals' lack of benevolence towards migrant children, but instead, were the ideological means at hand that school personnel used in order to represent their professional role and school environment as meaningful and just. By saying that migrant children are on average managing as well as others, they testified to a belief that every child is equal and that they do not fall into stereotyping and prejudice.

The differing views on migrant children's wellbeing among school welfare personnel and migrant parents have to be examined in the context of hegemony. The unwillingness to explicitly group their "clients" according to some background characteristics, be it ethnic identification or socio-economic position of the family, shows that the school welfare professionals in multicultural comprehensive schools are implicitly or explicitly aware of the critique presented against service providers as power holders which makes them careful about the light in which they present themselves in interviews (cf. Hagelund 2009 on street-level bureaucrats in Norway). Discriminatory bullying and child abuse were evidently the topics that are most difficult to address as the power imbalance between service providers and their minority clients is most explicit in these issues. Child abuse was acknowledged as the most problematic issue to deal 
with, juxtaposing some of the most fundamental values of cultural self-determination and child protection (see also Anis 2008).

The tension in the views on child wellbeing between school welfare personnel and migrant parents is evident and has repercussions for school health promotion. The worlds of the migrant home and Finnish school appear as worlds apart, despite the goodwill that generally exists in school welfare services and the interest that migrant parents pay to school achievement of their children (Säävälä 2012). Although the majority of migrant children cope well in school and do not face direct risks of social exclusion and marginalization, they form one of the vulnerable groups in Finnish society. In order to strengthen the positive sources of resilience among migrant children, it is important to understand how school welfare personnel see migrant children and adolescents.

This study shows that one of the important tendencies among school welfare personnel is to downplay the differences and to stress individuality. Although this can be regarded as a positive starting point, it has some negative implications. If school personnel fail to understand the power imbalance between school and migrant home, unrecognizing itself as a representative of public power - not only as providers of support (Dean 1999) - they find it difficult to secure constructive cooperation between migrant parents and the school for the benefit of the children. It would be important to sensitize the school welfare personnel to recognize (also latent) fear among migrant parents of not being treated fairly in order to build up trust through day-to-day interaction between home and school. This trust is necessary if and when interventions are imperative for child wellbeing.

\section{Acknowledgements}

This study was carried out as part of the research consortium ETNOKIDS which is funded by the Academy of Finland (grant no 134 918) and the European Integration Fund. I would like to thank the principal investigator of the consortium Tiina Laatikainen and the head of Väestöliitto's part of ETNOKIDS, Ismo Söderling as well as all the colleagues in the project for their support and enthusiasm. I would also like to thank Anna Rotkirch, Anne Alitoppa-Niitamo, Elina Leinonen and Anna Weckström and the anonymous reviewers for their valuable advice and comments. 


\section{References}

Alitolppa-Niitamo, Anne. 2010. Perheen akkulturaatio ja sukupolvien väliset suhteet. In: Maahanmuutto ja sukupolvet, edited by Tuomas Martikainen ja Lotta Haikkola, pp. 45-64. Helsinki: SKS.

Anis, Merja. 2008. Sosiaalityö ja maahanmuuttajat. Lastensuojelun ammattilaisten ja asiakkaiden vuorovaikutus ja tulkinnat. Population Research Institute Publications D47. Helsinki: Väestöliitto.

Basic Education Act 628/1998

Child Welfare Act L417/2007

City of Helsinki Education Department. 2010. Opetusviraston vuosikertomus 2010. In http://www.hel.fi/wps/wcm/connect/6c52a98042423e4999ccd9a1adf32673/ Vuosikertomus_fin_28+4+2011.pdf?MOD=AJPERES\&CACHEID=6c52a98042 423e4999ccd9a1adf32673, accessed 17th April 2012.

City of Helsinki Urban Facts, Espoon kaupungin kehittämis- ja tutkimusyksikkö, Vantaan kaupunki, tietopalveluyksikkö. 2010. Vieraskielisen väestön ennuste Helsingin seudulla 2010-2030. Accessed 14.12.2012.

Dean, Mitchell. 1999. Governmentality. Power and Rule in Modern Society. London: Sage.

Goodman, Anna, Vikram Patel and David A Leon. 2008. Child mental health differences amongst ethnic groups in Britain: A systematic review. BMC Public Health 8:258 (25 July 2008).

Gray, Gay, Ian Young and Vivian Barnekow. 2006. Developing a health-promoting school: a practical resource for developing effective partnerships in school health, based on the experience of the European Network of Health Promoting Schools. European Network of Health Promoting Schools, accessed 14.12.2012

Hagelund, Anniken. 2009. Dealing with the dilemmas: Integration at the street-level in Norway. International Migration 48(2):79-102.

Hermanson, Elina and Anni Lommi. 2009. Maahanmuuttajataustaiset nuoret haaste kouluterveydenhuollolle. Suomen Lääkärilehti 64(11): 1009-1015.

Hintzpeter, B., C. Scheidt-Nave, M.J. Müller, L. Schenk, and G.B. Mensink. 2008. Higher prevalence of vitamin D deficiency is associated with immigrant background among children and adolescents in Germany. Journal of Nutrition 138(8):1482-90.

Honkasalo, Veronika. 2011. Tyttöjen kesken. Monikulttuurisuus ja sukupuolten tasaarvo nuorisotyössä. Nuorisotutkimusverkosto / Nuorisotutkimusseura, julkaisuja 109. Helsinki.

Hsieh, H.-F., and S.E. Shannon. (2005). Three approaches to qualitative content analysis. Qualitative Health Research 15(9): 1277-1288.

Konu, Anne and Matti Rimpelä. 2002. Wellbeing in schools: A conceptual model. Health Promotion International 17(1): 79-87.

Käriäinen, Juha, Noora Ellonen, Laura Peutere, and Heikki Sariola. 2010. Lapset ja nuoret väkivallan uhreina: Maahanmuuttajien ja kantasuomalaisten vertailua. Yhteiskuntapolitiikka 75(2): 159-174.

Malin, Maili. 2011. Maahanmuuttajien terveyteen ja hyvinvointiin vaikuttavat tekijät. Yhteiskuntapolitiikka 76(2): 201-213. 
Malin, Maili, Tiina Laatikainen, Minna Säävälä, and Anne Alitolppa-Niitamo. 2011. Maahanmuuttajataustaisten nuorten terveys ja hyvinvointitutkimus alkaa. Hyvinvointikatsaus 3/ 2011:95-98.

Patton, M.Q. 2002. Qualitative Research and Evaluation Methods. Thousand Oaks, CA: Sage.

Rastas, Anna. 2007. Rasismi lasten ja nuorten arjessa: transnationaalit juuret ja monikulttuuristuva Suomi. Tampere: Tampere University Press and Nuorisotutkimusverkosto.

Rimpelä, Matti, Sari Fröjd and Heidi Peltonen. (eds). 2010. Hyvinvoinnin ja terveyden edistäminen perusopetuksessa 2009. Perusraportti. Koulutuksen seurantaraportit 2010:1. Helsinki: Opetushallitus.

Roos, J. P. 1988. Behind the happiness barrier. Helsinki: University of Helsinki.

Räsänen, Meiju and Joel Kivirauma. 2011. Oppilaana monikulttuurisessa koulussa. In Vieraina koulussa? Monikulttuurinen koulu oppilaiden, vanhempien, opettajien ja rehtoreiden kokemana, edited by Kirsi Klemelä, Anne Tuittu, Arja Virta and Risto Rinne. Turun yliopisto, kasvatustieteiden tiedekunta, julkaisusarja A:211, 35-95.

Säävälä, Minna. 2012. Koti, koulu ja maahan muuttaneiden lapset: Oppilashuolto ja vanhemmat hyvinvointia turvaamassa. Population Research Institute E 43/2012. Helsinki: Väestöliitto.

Soilamo, Arto. 2007. Maahanmuuttajaoppilaan osallisuus koulukiusaamisessa. Ph.D. Thesis. University of Turku, Faculty of Education.

Souto, Anne-Mari. 2011. Arkipäivän rasismi koulussa. Etnografinen tutkimus suomalais-ja maahanmuuttajanuorten ryhmäsuhteista. Nuorisotutkimusverkosto, julkaisuja 110. Helsinki: Nuorisotutkimusverkosto/ Nuorisotutkimusseura.

Stevens, G.W. and W.A. Vollebergh. 2008. Mental health in migrant children. Journal of Child Psychology and Psychiatry 49(3):276-94.

Strohmeier, Dagmar, Antti Kärnä and Christina Salmivalli. 2011. Intrapersonal and Interpersonal Risk Factors for Peer Victimization in Immigrant Youth in Finland. Developmental Psychology 47(1): 248-258.

Statistics Finland. 2011. Ulkomaalaiset ja siirtolaisuus 2009. Helsinki: Tilastokeskus. Statistics Finland. 2010. Perheet 2009. Helsinki: Tilastokeskus.

Suarez-Orozco Carola and Marcelo M. Suarez-Orozco. 2001. Children of Immigration. Cambridge: Harvard University Press.

Syrjänen, Nina. 2008. Maahanmuuttajaäitien kokemuksia ja akkulturaatiota koulun kontekstissa. Unpublished Master's Thesis. Department of Social Psychology, University of Helsinki.

Vaarama, Marja, Pasi Moisio ja Karvonen, Sakari (eds.). 2010. Suomalaisten hyvinvointi 2010. Helsinki: National Institute of Health and Wellbeing.

Warsame, Saeed. 2010. School for all? Home-school cooperation and school development as conditions for supporting Somali children's learning. Finnish Journal of Ethnicity and Migration 5(3): 17-26, accessed 14.12.2012.

Weckström, Anna 2011. Oman äidinkielen opettajat kodin ja koulun välisessä vuorovaikutuksessa. Unpublished Master's Thesis. Faculty of Social Sciences and Business Studies, University of Eastern Finland. 